\title{
SUPERCRITICAL FLUID EXTRACTION WITH CARBON DIOXIDE AT DIFFERENT PRESSURES
}

\author{
V. Mićićl, ${ }^{\prime}$, D. Novaković ${ }^{2}$, Ž. Lepojević ${ }^{3}$, M. Jotanovićl, \\ B. Pejovićl ${ }^{1}$, P. Dugićl ${ }^{1}, Z$. Petrovic ${ }^{1}$ \\ ${ }^{1}$ Faculty of Technology Zvornik, University of Eastern Sarajevo, \\ ${ }^{2}$ Faculty of Technical Sciences, University of Novi Sad, Serbia \\ ${ }^{3}$ Faculty of Technology, University of Novi Sad, Serbia
}

\begin{abstract}
In this paper the influence of carbon dioxide pressure on supercritical extraction of Salvia officinalis L. was investigated. Supercritical fluid extraction with carbon dioxide was done for pressures of 80, 100, 150, 200 and 300 bar. It was concluded that with increasing pressure from 80 to 300 the bar extraction yield enhanced. GC/MS and GC/FID methods were used for qualitative and quantitative analyses of obtained extracts and essential oils from extracts.
\end{abstract}

Keywords: supercritical extraction, carbon dioxide, pressures, sage, essential oil.

\section{INTRODUCTION}

With increasing public interest in herbal medicine and natural products, the conventional methods such as hydro-distillation and solvent extraction were found unsatisfactory $[1,2]$.

The distillation procedure allows only the separation of volatile compounds (essential oils), which, to a greater or lesser extent, are transformed under the influence of increased temperature. On the other hand, extraction with organic solvents can hardly render an extract free of traces of the organic solvent, which are undesirable for either organoleptic and/or health reasons. Besides, organic solvents are insufficiently selective, so that, in addition to the active substances, they also dissolve some concomitant compounds $[3,4]$. To improve efficiency and selectivity of the extraction, alternative extraction techniques as supercritical extraction were developed [6].

The broad interest in supercritical $\mathrm{CO}_{2}$ extraction (SFE) of essential oils is proved by large number of scientific literature published on this argument. These studies were undertaken in view of a possible industrial application of the process. Supercritical extraction is not widely used yet, but as new technologies are coming there are more and more viewpoints that could justify it, such as high purity, residual solvent content and environment protection $[1,2,3]$. Some of the advantages that the extraction process by supercritical fluids compa-

\footnotetext{
${ }^{*}$ Corresponding author: vlado21micic@ptt.rs
}

red to extraction by conventional liquid solvents for separations has are as follows:

- dissolving power of the SCF (supercritical fluid) is controlled by pressure and/or temperature,

- SCF is easily recoverable from the extract due to its volatility:

- non-toxic solvents leave no harmful residue

- high boiling components are extracted at relatively low temperatures,

- thermally labile compounds can be extracted with minimal damage as low temperatures can be employed by the extraction.

On the other hand, this method has some disadvantages such as:

- elevated pressure required,

- compression of solvent required,

- elaborate recycling to reduce energy costs

- high capital investment for equipment.

The choice of SFE solvent is similar to the regular extraction.

Principle considerations are the following:

- good solving property,

- inert to the product,

- easy separation from the product,

- cheap.

Carbon dioxide is most widely used in SFE because it is simple to use, inexpensive, nonflammable, nontoxic, chemically stable, shows great affinity to volatile (lipophilic) compounds, and can be easily and completely removed from any extrac $\mathrm{t}[2,4,5,6]$. By changing pressure and /or temperature above critical point of carbon dioxide $\left(\mathrm{Tc}=31,3^{\circ} \mathrm{C}\right.$, 
$\mathrm{Pc}=72,8$ bar,) a pronounced change in the density and dielectric constant, i.e. solvent power of supercritical carbon dioxide can be achieved.

The special properties of supercritical fluids bring certain advantages to chemical separation processes. Several applications have been fully developed and commercialized [6,7]. The biggest application is in the decoffeinization of tea and coffee. A process of removal of caffeine from coffee using supercritical carbon dioxide was patented in the United States in 1974, and a commercial plant went on stream in the FRG in 1978. Other important areas are the extraction of essential oils and aroma materials from spices. Brewery industry uses SFE for the extraction of hop. The method is used in extracting some edible oils and producing cholesterine-free egg powder.

In this paper, SFE of essential oil from sage (Salvia officinalis L.) was investigated.

\section{EXPERIMENTAL}

\subsection{Plant Material}

For this experiment Salvia officinalis L. from Berkovici, near Trebinje gathered 2008 was used.

\subsection{Chemicals}

Commercial carbon dioxide $(99 \%$ purity, Tehno-gas, Novi Sad, Serbia) as the extracting agent was used. All other chemicals were of analytical reagent grade.

\subsection{Chromatographic procedures:}

MS, Finnigan - MAT 8230 BE geometry, resolution 1000, EI - CIU source at $200^{\circ}$. EI $70 \mathrm{eV}$, $0.5 \mathrm{~mA}$; CI, 1 mtorr of isobutane $150 \mathrm{eV} 0.2 \mathrm{~mA}$.

GC/MS, Varian 3400 GC equipped with Split/Splitless injector (1:99) operated at $244^{\circ}$. Column J\&W Scientific DB-5ms-ITD 30m, $0.25 \mathrm{~mm}$ id, $0.25 \mu \mathrm{m}$ film. Carrier gas hydrogen, $1 \mathrm{ml} / \mathrm{min}$ measured at $210^{\circ}$. Column temperature was linearly programmed from $40^{\circ}$ to $285^{\circ}$ at $4.3^{\circ} / \mathrm{min}$. Transfer line at $270^{\circ}$, coupled to Finnigan-MAT $8230 \mathrm{BE}$ mass spectrometer. Ion source temperature $170 \mathrm{O}$, EI, $70 \mathrm{eV} 0.1 \mathrm{~mA}$. Scan range 33-333/ $1 \mathrm{sec}$.

GC, HP5890 series II 3400 GC equipped with Split/Splitless injector (1:99) operated at $244^{\circ}$. Column J\&W Scientific DB-5ms-ITD 30m, 0.25mm id, $0.25 \mu \mathrm{m}$ film. Carrier gas hydrogen, $1 \mathrm{ml} / \mathrm{min}$ measured at $210^{\circ}$. Column temperature was linearly programmed from $40^{\circ}$ to $285^{\circ}$ at $4.3^{\circ} / \mathrm{min}$.

\subsection{Supercritical Fluid Extraction}

SFE by $\mathrm{CO}_{2}$ was carried out with a laboratory - scale high - pressure extraction plant (NOVA Swiss, Effretikon, Switzerland), shown in Figures 1. The main parts and characteristics (manufacturer specification) of the plant were as follows: a diaphragm - type compressor (up to 1000 bar), extractor with an internal volume of $200 \mathrm{~mL}$ (Pmax $=250 \mathrm{bar}$ ), and maximum $\mathrm{CO}_{2}$ mass flow rate of approximately $5.7 \mathrm{~kg} / \mathrm{h}$.

The mass of Salvia sample in extractor was $60 \mathrm{~g}$ at the investigated value of pressure and at temperature $40^{\circ} \mathrm{C}$, and the $\mathrm{CO}_{2}$ flow rate was $97.72 \mathrm{dm}^{3} / \mathrm{h}$. Separator conditions were pressure 15 bar and temperature $25^{\circ} \mathrm{C}$.

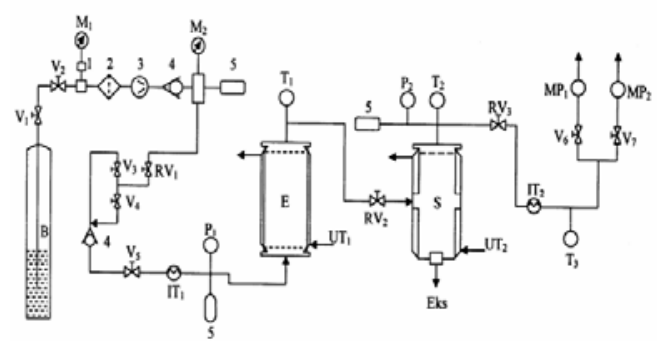

Fig. 1. Laboratory scale high pressure SFE plant

\section{RESULTS AND DISCUSSION}

The supercritical fluid extraction (SFE) of Salvia officinalis L. by carbon dioxide $\left(\mathrm{CO}_{2}\right)$ was investigated in order to obtain the best conditions. Experiments were performed at different pressures $(80,100,150,200$ and 300 bar), all other extraction conditions were the same (extraction time $\tau=4 \mathrm{~h}$, $\mathrm{CO}_{2}$ flow rate $\mathrm{w}=3.225 \cdot 10^{-3} \mathrm{~kg} / \mathrm{min}$, mean particle diameter $\mathrm{d}=0.32 \mathrm{~mm}$, temperature $\mathrm{t}=40^{\circ} \mathrm{C}$ ).

In order to prevent thermal decomposition of some volatile oil compounds, the temperature of supercritical fluid extraction of $40^{\circ} \mathrm{C}$ was selected. The pressure range of $80-300$ bar (a pronounced change in the density and dielectric constant, i.e. solubility power of carbon dioxide) for SFE of Salvia officinalis L. was investigated. The selection of pressure ranges is based on the fact that a great change in the density and dielectric constant of $\mathrm{CO}_{2}$ occurs between 80 and 150 bar.

Investigation of extraction kinetic for extraction system sage - supercritical carbon dioxide in the function of pressure was shown in the figure 2. 


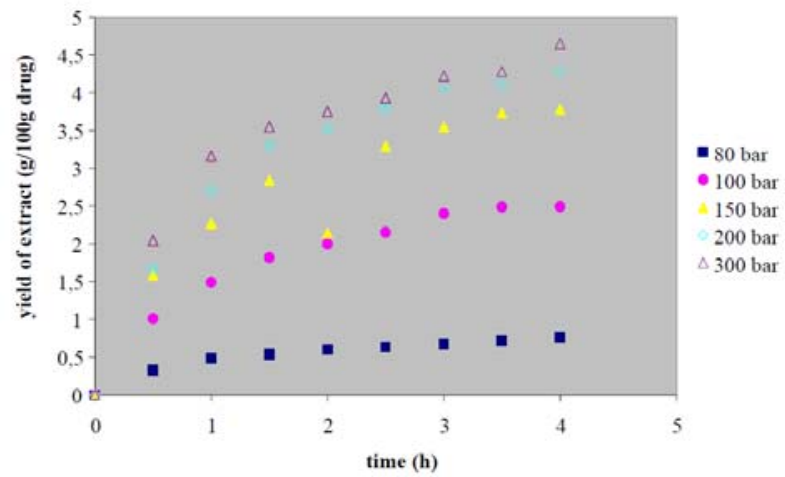

Results showed that with increasing pressure from 80 to 300 bar the extraction yield enhanced, which was due to the increased $\mathrm{SCCO}_{2}$ density at higher pressures. $\mathrm{CO}_{2}$ extracts and essential oils obtained from $\mathrm{CO}_{2}$ extracts were subjected to detailed identification and quantification using GC/MS and GC/FID methods. The results of qualitative and quantitative analyses are given in table 1.

Fig. 2. Plots yield of extract vs. extraction time

Table 1. Qualitative and quantitative content of $\mathrm{CO}_{2}-$ extract and essential oil obtained from $\mathrm{CO}_{2}$ extract

\begin{tabular}{|c|c|c|c|c|c|}
\hline \multirow{4}{*}{ Component } & \multicolumn{5}{|c|}{ Component content $(\%, \mathrm{~m} / \mathrm{m})$} \\
\hline & \multicolumn{5}{|c|}{$\mathrm{CO}_{2}$ extract/essential oil } \\
\hline & \multicolumn{5}{|c|}{ Pressure (bar) } \\
\hline & 80 & 100 & 150 & 200 & 300 \\
\hline$\beta$-pinene & $-/ 0.23$ & $-/ 0.20$ & $-/ 0.33$ & $-/ 0.62$ & $-/-$ \\
\hline 1,8 - cineole & $-/ 0.47$ & $-/ 1.77$ & $-/ 1.06$ & $-/ 2.88$ & $-/ 0.96$ \\
\hline$\alpha-$ thujone & $0.66 / 19.56$ & $4.44 / 26.28$ & $4.18 / 23.48$ & $3.77 / 27.38$ & $5.15 / 15.63$ \\
\hline$\beta$ - thujone & $-/ 3.30$ & $-/ 4.11$ & $0.19 / 3.57$ & $0.70 / 4.17$ & $-/ 2.44$ \\
\hline camphor & $1.43 / 19.56$ & $11.93 / 22.95$ & $11.37 / 23.45$ & $14.88 / 23.06$ & $15.24 / 16.03$ \\
\hline isoborneole & $11.29 / 9.12$ & $7.39 / 9.89$ & $6.80 / 12.11$ & $9.52 / 7.94$ & $8.17 / 8.16$ \\
\hline terpineol L - 4 & $2.08 / 0.78$ & $0.32 / 0.75$ & $0.25 / 0.89$ & $0.33 / 0.62$ & $0.30 / 0.54$ \\
\hline bornyl - acetate & $5.90 / 6.81$ & $3.59 / 4.33$ & $2.01 / 4.82$ & $4.62 / 3.74$ & $3.96 / 3.51$ \\
\hline sabinyl - acetate & $1.05 / 0.86$ & $0.53 / 0.51$ & $0.41 / 0.55$ & $0.64 / 0.43$ & $0.42 / 0.43$ \\
\hline isocaryophyllene & $2.74 / 2.10$ & $1.18 / 1.21$ & $0.84 / 1.39$ & $1.30 / 1.05$ & $1.17 / 1.01$ \\
\hline$\alpha-$ gurjunene & $1.45 / 0.88$ & $0.54 / 0.42$ & $0.44 / 0.63$ & $0.62 / 0.49$ & $0.55 / 0.34$ \\
\hline$\gamma$ - elemene & $24.98 / 15.52$ & $9.31 / 8.66$ & $7.02 / 9.86$ & $9.73 / 7.46$ & $9.00 / 7.76$ \\
\hline selina $-3,7$ (11) diene & $11.25 / 5.60$ & $12.17 / 5.61$ & $13.83 / 6.46$ & $12.51 / 5.85$ & $12.14 / 8.64$ \\
\hline 1,11 - epoxyhumulene & $8.99 / 3.67$ & $4.56 / 2.01$ & $5.87 / 2.12$ & $4.96 / 1.98$ & $4.92 / 2.85$ \\
\hline caryophyllene oxide & $2.76 / 0.97$ & $2.66 / 0.87$ & $2.64 / 0.93$ & $2.39 / 0.97$ & $2.46 / 1.73$ \\
\hline phyllocladene & $10.42 / 4.19$ & $26.06 / 6.27$ & $30.64 / 4.75$ & $21.99 / 6.90$ & $24.60 / 23.37$ \\
\hline Total & $85.00 / 93.70$ & $84.70 / 96.10$ & $86.50 / 96.40$ & $88.00 / 95.50$ & $88.10 / 93.50$ \\
\hline
\end{tabular}

Component contents in extracts varied in the function of pressure. The extracts obtained at pressure 150 and 200 bar consists $\beta$ - thujone, other extracts does not consists $\beta$ - thujone. Dominant components in extracts are phyllocladene, $\gamma$ elemene, isoborneole,

selina $-3,7$ (11) diene, camphor, 1,11 epoxyhumulene. Content of phyllocladene in extract obtained at presure $p=80$ bar is $10.42 \%$, in other extracts content is from 21.99 to $30.64 \%$. Extract obtained on the pressure $p=80$ bar has the least content of camphor (1.43\%). In other extracts contents are from 11.37 to $15.24 \%$. Extract obtained on pressure $p=80$ bar has $\gamma$ - elemenae $24.98 \%$. Extracts obtained on pressures 100, 150, 200 and
300 bar have $\gamma$ - elemenae from 7.02 to $9.73 \%$. In extract obtained on pressure $\mathrm{p}=80$ bar there are 1,11 - epoxyhumulene $(8.99 \%)$, in other extracts $(4.56-$ $5.87 \%$ ). The content of Selina 3,7 (11) diene is approximately equal in all obtained extracts (11.25 $13.83 \%)$.

\section{CONCLUSION}

We can conclude that the solubility of investigated sage is equal to their yield. So it could be concluded that sage solubility increases by increasing carbon dioxide pressure, i.e. density or solubility power of extragent. According to the 
results of this study, SFE offered more choices (pressures level) for the extraction of different components.

\section{REFERENCES}

[1] H. Sovova, Mathematical model for supercritical fluid extraction of natural products and extraction curve evaluation, J. Supercritical Fluids 33 (2005) 35-52.

[2] F. Stampar, A. Solar, M. Hudina, R. Veberic, M. Colaric, Traditional walnut liqueurcocktail of phenolics, Food Chem. 95 (2006) 627-631.

[3] Z. Zeković, Ž. Lepojević, S. Milošević, A. Tolić, Thyme (Thymus vulgaris L.) compounds in SFE, Proceedings 6th Conference on Supercritical Fluids and Their Applications, Maiori, Italy, September, 2001, 209
[4] E. Reverchon, F. Senatore, Isolation of rosemary oil: Comparison between hydrodistillation and supercritical $\mathrm{CO}_{2}$ extraction. Flavour and Fragrance Journal 7 (2005) 227-230.

[5] K. Cheng, S. Kuo, M. Tang, Y. Chen, Vapor-liquid equilibria at elevated pressures of binary mixtures of carbon dioxide with methyl salicylate, eugenol and diethyl phthalate, Supercritical Fluids 18 (2000) 87-99.

[6] T. M. Takeuchi, M. L. Corazza, M. A. Meireles, Study of the phase equilibrium formed inside the flash tank used at the separation step of a supercritical fluid extraction unit, J. Supercritical Fluids 43 (2008), 447-459.

[7] W. Guan, S. Li, R. Yan, S. Tang, C. Quan, Comparison of essential oils of clove buds extracted with supercritical carbon dioxide and other three traditional methods, Food Chem. 101 (2007), $1558-1564$.

$\operatorname{son}$

\section{СУПЕРКРИТИЧНА ЕКСТРАКЦИЈА СА УГЉЕН-ДИОКСИДОМ ПРИ РАЗЛИЧИТИМ ПРИТИСЦИМА}

Извод: У оквиру овог рада испитиван је утицај притиска угљен-диоксида као растварача при суперкритичној екстракцији жалфије (Salvia Officinalis L.). Екстракција је вршена при притисцима од 80, 100, 150, 200 и 300 bar при чему је одређиван принос тоталног (укупног) екстракта. Закључено је да се са повећањем притиска од 80 на 300 bar повећавао принос тоталног екстракта. Извршена је и квалитативна и квантитативна анализа добијених екстраката и етарских уља GC/MS и GC/FID методама.

Кључне речи: суперкритична екстракција, угљен-диоксид, притисак, жалфија, етарско уље. 